\title{
An Analysis of Agriculture Sector in Indian Economy
}

\author{
Himani \\ Assistant Professor in Economics, Guru Nanak Khalsa College Yamuna Nagar, Haryana
}

\begin{abstract}
Agriculture sector also known as primary sector is essential for economic growth in any economy including India. It has emerged as the essential-growing sector in the global economy since independence. This sector contributing 13.7 per cent of GDP. In employment providing, this sector is occupying first place. Its respectable share in foreign direct investment (FDI) inflows as well as in total exports makes it the engine of economic growth. Keeping in above backdrop, the present study makes an analysis of agriculture sector in Indian economy. The study confirms that agriculture sector has achieved tremendous growth over the year in Indian economy. Besides, their contributions in GDP, employment and exports are also rising considerably. To maintain and accelerate the growth \& contributions of this sector \& to develop it as a true engine of economic growth, there is logic \& rationale of complementary investments in physical infrastructure as well as in human capital.
\end{abstract}

\section{Introduction}

Agriculture is the Primary sector of Economy. It makes direct use of natural resources. It is contrasted with secondary sector( producing manufactured\& other processed goods) \& the Tertiary sector (producing services). This sector is usually most important in less developed countries \& typically less important in industrial countries.Until the industrial revolution, Vast majority of human population labored in agriculture. Pre Industrial agriculture was typically subsistent in which farmers raised most of their crop for their own consumption instead of cash crop for trade. A remarkable shift in agriculture practices has occurred over the past century in response of new technology \& the development of world market. This also led to technological improvements in agricultural techniques. Now, Agriculture with its allied sector is unquestionably the largest livelihood provider in India, more so in the vast rural area.It also contributes a significant figure to GDP. Most of the industries also depend on agriculture sector for their raw materials. The planned approach to development has helped the country to reach a stage where the country is self sufficient in food grains and has a comfortable buffer stock. These achievements have been possible mainly through the favourable policy framework. The policy of Indian Agriculture was to achieve food security by providing incentive for growth alongwith equitable access to food. As a result terrible famineshave become events of the past and the agricultural production does not show large variation even in the event of adverse climatic condition.

\section{Accomplishments}

As of 2011, India had a large and diverse agricultural sector, accounting, on average, for about $16 \%$ of GDP and $10 \%$ of export earnings. India's arable land area of 159.7 million hectares (394.6 million acres) is the second largest in the world, after the United States. Its gross irrigated crop area of 82.6 million hectares (215.6 million acres) is the largest in the world. India has grown to become among the top three global producers of a broad range of crops, including wheat, rice, pulses, cotton, peanuts, fruits, and vegetables. Worldwide, as of 2011, India had the largest herds of buffalo and cattle, is the largest producer of milk, and has one of the largest and fastest growing poultry industries.

The following table presents the twenty most important agricultural products in India, by economic value, in 2009. Included in the table is the average productivity of India's farms for each produce. For context and comparison, included is the average of the most productive farms in the world and name of country where the most productive farms existed in 2010. The table suggests India has large potential for further accomplishments from productivity increases, in increased agricultural output and agricultural incomes

Table 1 Agriculture in India, largest crops by Economic value

\begin{tabular}{|l|l|l|l|l|l|l|}
\hline & & $\begin{array}{l}\text { Economic } \\
\text { value }\end{array}$ & Unit price & $\begin{array}{l}\text { Average yield, India } \\
(\mathbf{2 0 1 0})\end{array}$ & \multicolumn{2}{l|}{$\begin{array}{l}\text { World's most productive farms } \\
(\mathbf{2 0 1 0})\end{array}$} \\
\hline Rank & Produce & $\begin{array}{l}(2009 \text { prices, } \\
\text { US\$) }\end{array}$ & $\begin{array}{l}\text { (US\$ / } \\
\text { kilogram) }\end{array}$ & tonnes per hectare & $\begin{array}{l}\text { (tonnes } \\
\text { per } \\
\text { hectare })\end{array}$ & Country \\
\hline 1 & Rice & $\$ 38.42$ billion & .27 & 3.3 & 10.8 & Australia \\
\hline 2 & Buffalo milk & $\$ 2.46$ billion & .4 & 1.7 & 1.9 & Pakistan \\
\hline 3 & Cow milk & $\$ 17.13$ billion & .31 & 1.2 & 10.3 & Israel \\
\hline
\end{tabular}


An Analysis Of Agriculture Sector In Indian Economy

\begin{tabular}{|c|c|c|c|c|c|c|}
\hline 4 & Wheat & $\$ 12.14$ billion & .15 & 2.8 & 8.9 & Netherlands \\
\hline 5 & Mangoes & $\$ 9$ billion & .6 & 6.3 & 40.6 & Cape Verde \\
\hline 6 & Sugar cane & $\$ 8.92$ billion & .03 & 66 & 125 & Peru \\
\hline 7 & Bananas & $\$ 8.38$ billion & .28 & 37.8 & 59.3 & Indonesia \\
\hline 8 & Cotton & $\$ 8.13$ billion & 1.43 & 1.6 & 4.6 & Israel \\
\hline 9 & $\begin{array}{l}\text { Fresh } \\
\text { Vegetables }\end{array}$ & $\$ 5.97$ billion & .19 & 13.4 & 76.8 & USA \\
\hline 10 & Potatoes & $\$ 5.67$ billion & .15 & 19.9 & 44.3 & USA \\
\hline 11 & Tomatoes & $\$ 4.59$ billion & .37 & 19.3 & 524.9 & Belgium \\
\hline 12 & Buffalo meat & $\$ 4$ billion & 2.59 & .136 & .424 & Thailand \\
\hline 13 & Soybean & $\$ 3.33$ billion & .26 & 1.1 & 3.7 & Turkey \\
\hline 14 & Onions & $\$ 3.17$ billion & .21 & 16.6 & 67.3 & Ireland \\
\hline 15 & Chicken Meat & $\$ 3.12$ billion & .64 & 10.6 & 20.2 & Cyprus \\
\hline 16 & Chick peas & $\$ 3.11$ billion & .4 & 0.9 & 2.8 & China \\
\hline 17 & Okra & $\$ 3.07$ billion & .35 & 7.6 & 23.9 & Israel \\
\hline 18 & Cattle Meat & $\$ 2.93$ billion & .83 & 13.8 & 24.7 & Jordan \\
\hline 19 & Eggs & $\$ 2.80$ billion & 2.7 & .12 & .42 & Japan \\
\hline 20 & Beans & $\$ 2.57$ billion & .82 & 1.1 & 5.5 & Nicaragua \\
\hline
\end{tabular}

The Statistics Office of the Food and Agriculture Organization reported that, per final numbers for 2009, India had grown to become the world's largest producer of the following agricultural produce

- Fresh Fruit

- Lemons and limes

- Buffalo milk - whole, fresh

- Castor oil seeds

- Sunflower seeds

- Sorghum

- Millet

- Spices

- Okra

- Jute

- Beeswax

- Bananas

- Mangoes, mangos teens, guavas

- Pulses

- Indigenous Buffalo Meat

- Fruit, tropical

- Ginger

- Chick peas

- Areca nuts

- Other Bastfibres

- Pigeon peas

- Papayas

- Chilies and peppers, dry

- Anise, Badin, fennel, coriander

- Goat milk, whole, fresh

Per final numbers for 2009, India is the world's second largest producer of the following agricultural produce

- Wheat

- Rice

- Vegetables, fresh

- Sugar cane

- Groundnuts, with shell

- Lentils

- Garlic

- Cauliflowers and broccoli

- Peas, green

- Sesame seed

- Cashew nuts, with shell

- Silk-worm cocoons, reel able

- Cow milk, whole, fresh

- Tea 
- Potatoes

- Onions

- Cotton lint

- Cottonseed

- Eggplants

- Nutmeg, mace and cardamoms

- Indigenous Goat Meat

- Cabbages and other brassicas

- $\quad$ Pumpkins, squash and gourds

In 2009, India was the world's third largest producer of eggs, oranges, coconuts, tomatoes, peas and beans

\section{Importance Of Agriculture}

Agriculture plays a crucial role in the life of an economy. It is the backbone of our economic system. Agriculture not only provides food and raw material but also employment opportunities to a very large proportion of population. The following facts clearly highlight the importance of agriculture in this country.

\section{Source of Livelihood:}

In India the main occupation of our working population is agriculture. About 70 per cent of our population is directly engaged in agriculture. In advanced countries, this ratio is very small being 5 per cent in U.K., 4 per cent in USA., 16 per cent in Australia, 14 per cent in France, 21 per cent in Japan and 32 per cent in USSR.This high proportion in agriculture is due to the fact that the non-agricultural activities have not been developed to absorb the rapidly growing population.

\section{Contribution to National Income:}

Agriculture is the premier source of our national income. According to National Income Committee and C.S.O., in 1960-61, 52 per cent of national income was contributed by agriculture and allied occupations. In 1976-77, this sector alone contributed 42.2 per cent while in 1981-82, its contribution was to the tune of 41.8 per cent.In 2001-02, it contributed around 32.4 per cent of national income. This was further reduced to 28 per cent in 1999-2000. Contrary to this, the proportion of agriculture in U.K. is only 3.1, in USA it is 3 percent, 2.5 per cent in Canada, 6 per cent in Japan, 7.6 per cent in Australia.The mere conclusion of all this is that more developed a country the smaller is the contribution of agriculture in national output.

\section{Supply of Food and Fodder:}

Agriculture sector also provides fodder for livestock (35.33 crores). Cow and buffalo provide protective food in the form of milk and they also provide draught power for farm operations. Moreover, it also meets the food requirements of the people. Import of food grains has been very small in recent years, rather export avenues are being looked for.

\section{Importance in International Trade:}

It is the agricultural sector that feeds country's trade. Agricultural products like tea, sugar, rice, tobacco, spices etc. constitute the main items of exports of India. If the development process of agriculture is smooth, export increases and imports are reduced considerably.Thus, it helps to reduce the adverse balance of payments and save our foreign exchange. This amount can be well utilized to import other necessary inputs, raw-material, machinery and other infra-structure which is otherwise useful for the promotion of economic development of the country.

\section{Marketable Surplus:}

The development of agricultural sector leads to marketable surplus. As country develops more and more people are to be engaged in mining, manufacturing and other non-agricultural sector. All these people depend upon the food production which they can meet from the marketable surplus.As agricultural development takes place, output increases and marketable surplus expands. This can be sold to other countries. Here, it is worth mentioning that the development of Japan and other countries were made possible by the surplus of agriculture. There is no reason why this could not be done in our own case.

\section{Source of Raw Material:}

Agriculture has been the source of raw materials to the leading industries like cotton and jute textiles, sugar, tobacco, edible and non-edible oils etc. All these depend directly on agriculture.Apart from this, many others like processing of fruits and vegetables, dal milling, rice husking, gur making also depend on agriculture 
for their raw material. According to United Nations Survey, the industries with raw material of agricultural origin accounted for 50 per cent of the value added and 64 per cent of all jobs in the industrial sector.

\section{Importance in Transport:}

Agriculture is the main support for railways and roadways which transport bulk of agricultural produce from farm to the mandies and factories. Internal trade is mostly in agricultural products. Besides, the finance of the govt, also, to the large extent, depends upon the prosperity of agricultural sector.

\section{Contribution to Foreign Exchange Resources:}

Agricultural sector constitutes an important place in the country's export trade. According to an estimate, agricultural commodities like jute, tobacco, oilseeds, spices, raw cotton, tea and coffee accounted for about 18 per cent of the total value of exports in India. This shows that agriculture products still continue to be significant source of earning foreign exchange.

\section{Vast Employment Opportunities:}

The agricultural sector is significant as it provides greater employment opportunities in the construction of irrigation projects, drainage system and other such activities.With the fast growing population and high incidence of unemployment and disguised unemployment in backward countries, it is only agriculture sector which provides more employment chances to the labour force. In this way, significance of agriculture emerges more and more.

\section{Overall Economic Development:}

In the course of economic development, agriculture employs majority of people. This means raising the level of the national income and standard of living of the common man.The rapid" rate of growth in agriculture sector gives progressive outlook and further motivation for development. As a result, it helps to create proper atmosphere for general economic development of the economy. Thus, economic development depends on the rate at which agriculture grows.

\section{Source of Saving:}

Improvement in agriculture can go a long way in increasing savings. It is seen that rich farmers have started saving especially after green revolution in the country.This surplus amount can be invested in agriculture sector for further; development of the sector. Saving potentials are large in agriculture sector which can be properly tapped for the development of the country.

\section{Source of Government Income:}

In India, many state governments get sizeable revenue from the agriculture sector. Land revenue, agricultural income tax, irrigation tax and some other types of taxes are being levied on agriculture by the state governments.Moreover, considerably revenue is earned by way of excise duty and export duty on agricultural products. Raj committee on Agricultural Taxation has suggested imposition of taxation on agricultural income for raising revenue.

\section{Basis of Economic Development:}

Prof. Nurkse has laid sufficient emphasis on the improvement of agriculture for a balanced growth of an economy. The development of agriculture provides necessary capital for the development of other sectors like industry, transport and foreign trade. In fact, a balanced development of agriculture and industry is the need of the day.

From the above, explanation it may be concluded that agriculture occupies an important place in the development of an economy. It is in fact, a pre-condition for economic up liftment. 


\section{India GDP Composition Sector Wise}

Table 2

\begin{tabular}{|l|c|c|c|c|c|}
\hline \multicolumn{1}{|c|}{ Industry } & $2010-11$ & $2011-12$ & Growth & \multicolumn{2}{c|}{ Weightage } \\
\hline Agricuiture, forestry \& Fishing & 709103 & 728667 & $2.76 \%$ & $14.01 \%$ & $14 \%$ \\
\hline Mining and Quarrying & 109421 & 108469 & $-0.87 \%$ & $2.08 \%$ & \multirow{1}{*}{$19 \%$} \\
\hline Manufacturing & 774162 & 793468 & $2.49 \%$ & $15.25 \%$ \\
\hline Electricity, Gas and Water Supply & 90944 & 98105 & $7.87 \%$ & $1.89 \%$ & \\
\hline Construction & 384199 & 404617 & $5.31 \%$ & $7.78 \%$ & \\
\hline Trade, Hotels, Transport \& Communication & 1330455 & 1462772 & $9.95 \%$ & $28.12 \%$ \\
\hline Financial, Insurance, Real Estate \& Business & 849995 & 931714 & $9.61 \%$ & $17.91 \%$ \\
\hline Community, Social \& Personal Services & 637675 & 674703 & $5.81 \%$ & $12.97 \%$ & \\
\hline Total & 4885954 & 5202515 & $6.48 \%$ & $100.00 \%$ & $100.00 \%$ \\
\hline
\end{tabular}

\section{Trade Of Agricultural Products:}

Reforms introduced in India in the early 1990s have greatly increased overall trade flows. However it has consistently run a trade deficit unlike China and Brazil (US\$35 billion in 2004-2005). The EU (27) ranks as India's largest trading partner accounting for about $21 \%$ of total Indian trade in 2005, ahead of the United States and China. Meanwhile India is the EU's tenth largest trading partner accounting for $1.8 \%$ of total trade. In 2005 its trade deficit with the EU was about $€ 2$ billion. Turning our focus to trade in agricultural and food products, these account for a relatively small share of overall Indian trade. Agricultural exports represent $9 \%$ of the value of total exports while the share of agriculture in total imports is just $5 \%$.

Figure 1

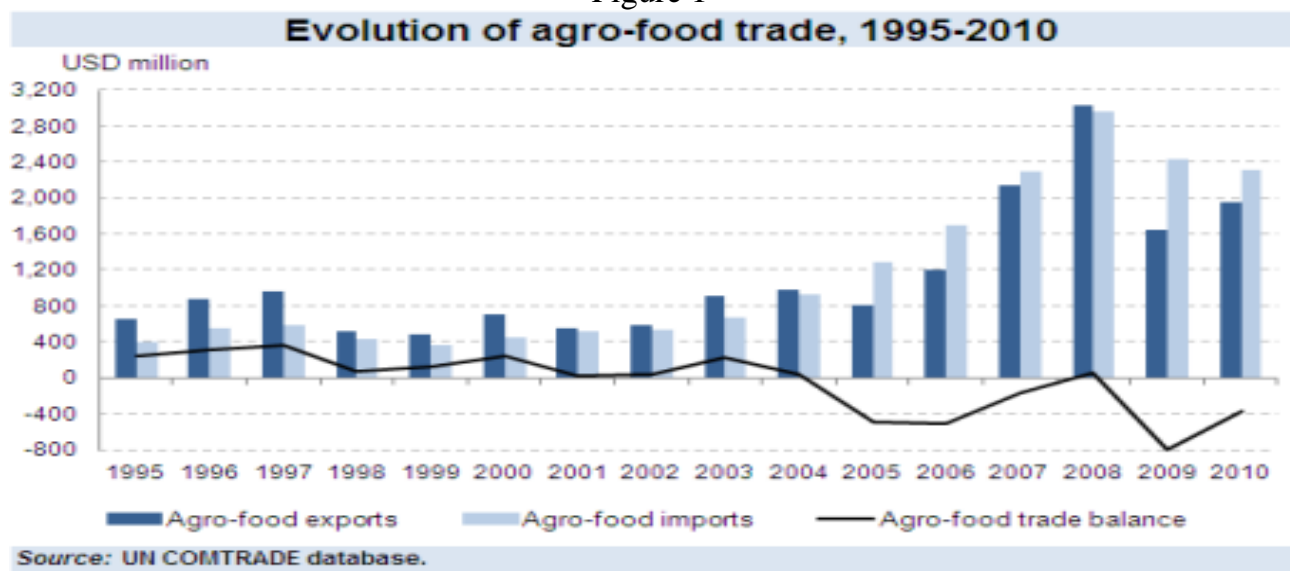

VI. India: Issues And Priorities For Agriculture

\section{$>$ CHALLENGES}

Three agriculture sector challenges will be important to India's overall development and the improved welfare of its rural poor:

1. Raising agricultural productivity per unit of land: Raising productivity per unit of land will need to be the main engine of agricultural growth as virtually all cultivable land is farmed. Water resources are also limited and water for irrigation must contend with increasing industrial and urban needs. All measures to increase productivity will need exploiting, amongst them: increasing yields, diversification to higher value crops, and developing value chains to reduce marketing costs.

2. Reducing rural poverty through a socially inclusive strategy that comprises both agriculture as well as non-farm employment: Rural development must also benefit the poor, landless, women, scheduled castes and tribes. Moreover, there are strong regional disparities: the majority of India's poor are in rain-fed areas or in the Eastern Indo-Gangetic plains. Reaching such groups has not been easy. While progress has been made - the rural population classified as poor fell from nearly $40 \%$ in the early 1990 s to below $30 \%$ by the mid-2000s (about a $1 \%$ fall per year) - there is a clear need for a faster reduction. Hence, poverty alleviation is a central pillar of the rural development efforts of the Government and the World Bank.

3. Ensuring that agricultural growth responds to food security needs: The sharp rise in food-grain production during India's Green Revolution of the 1970s enabled the country to achieve self-sufficiency in food-grains and stave off the threat of famine. Agricultural intensification in the 1970s to 1980s saw an increased demand for rural labor that raised rural wages and, together with declining food prices, reduced rural poverty. However agricultural growth in the 1990s and 2000s slowed down, averaging about $3.5 \%$ per annum, and cereal yields have increased by only $1.4 \%$ per annum in the $2000 \mathrm{~s}$. The slow-down in agricultural growth 
has become a major cause for concern. India's rice yields are one-third of China's and about half of those in Vietnam and Indonesia. The same is true for most other agricultural commodities.

Policy makers will thus need to initiate and/or conclude policy actions and public programs to shift the sector away from the existing policy and institutional regime that appears to be no longer viable and build a solid foundation for a much more productive, internationally competitive, and diversified agricultural sector.

\section{$>$ PRIORITY AREAS FOR SUPPORT}

\section{Enhancing agricultural productivity, competitiveness, and rural growth}

Promoting new technologies and reforming agricultural research and extension: Major reform and strengthening of India's agricultural research and extension systems is one of the most important needs for agricultural growth. These services have declined over time due to chronic underfunding of infrastructure and operations, no replacement of aging researchers or broad access to state-of-the-art technologies. Research now has little to provide beyond the time-worn packages of the past. Public extension services are struggling and offer little new knowledge to farmers. There is too little connection between research and extension, or between these services and the private sector.

2. Improving Water Resources and Irrigation/Drainage Management: Agriculture is India's largest user of water. However, increasing competition for water between industry, domestic use and agriculture has highlighted the need to plan and manage water on a river basin and multi-sectoral basis. As urban and other demands multiply, less water is likely to be available for irrigation. Ways to radically enhance the productivity of irrigation ("more crop per drop") need to be found. Piped conveyance, better on-farm management of water, and use of more efficient delivery mechanisms such as drip irrigation are among the actions that could be taken. There is also a need to manage as opposed to exploit the use of groundwater. Incentives to pump less water such as levying electricity charges or community monitoring of use have not yet succeeded beyond sporadic initiatives. Other key priorities include: (i) modernizing Irrigation and Drainage Departments to integrate the participation of farmers and other agencies in managing irrigation water; (ii) improving cost recovery; (iii) rationalizing public expenditures, with priority to completing schemes with the highest returns; and (iv) allocating sufficient resources for operations and maintenance for the sustainability of investments.

3. Facilitating agricultural diversification to higher-value commodities: Encouraging farmers to diversify to higher value commodities will be a significant factor for higher agricultural growth, particularly in rain-fed areas where poverty is high. Moreover, considerable potential exists for expanding agro-processing and building competitive value chains from producers to urban centers and export markets. While diversification initiatives should be left to farmers and entrepreneurs, the Government can, first and foremost, liberalize constraints to marketing, transport, export and processing. It can also play a small regulatory role, taking due care that this does not become an impediment.

Promoting high growth commodities: Some agricultural sub-sectors have particularly high potential for expansion, notably dairy. The livestock sector, primarily due to dairy, contributes over a quarter of agricultural GDP and is a source of income for $70 \%$ of India's rural families, mostly those who are poor and headed by women. Growth in milk production, at about $4 \%$ per annum, has been brisk, but future domestic demand is expected to grow by at least 5\% per annum. Milk production is constrained, however, by the poor genetic quality of cows, inadequate nutrients, inaccessible veterinary care, and other factors. A targeted program to tackle these constraints could boost production and have good impact on poverty.

4. Developing markets, agricultural credit and public expenditures: India's legacy of extensive government involvement in agricultural marketing has created restrictions in internal and external trade, resulting in cumbersome and high-cost marketing and transport options for agricultural commodities. Even so, private sector investment in marketing, value chains and agro-processing is growing, but much slower than potential. While some restrictions are being lifted, considerably more needs to be done to enable diversification and minimize consumer prices. Improving access to rural finance for farmers is another need as it remains difficult for farmers to get credit. Moreover, subsidies on power, fertilizers and irrigation have progressively come to dominate Government expenditures on the sector, and are now four times larger than investment expenditures, crowding out top priorities such as agricultural research and extension.

5.. Poverty alleviation and community actionsWhile agricultural growth will, in itself, provide the base for increasing incomes, for the 170 million or so rural persons that are below the poverty line, additional measures are required to make this growth inclusive. For instance, a rural livelihoods program that empowers communities to become self-reliant has been found to be particularly effective and well-suited for scaling-up. This program promotes the formation of self-help groups, increases community savings, and promotes local initiatives to increase incomes and employment. By federating to become larger entities, these institutions of the poor gain the strength to negotiate better prices and market access for their products, and also gain the political power over local governments to provide them with better technical and social services. These self-help groups are particularly effective at reaching women and impoverished families. 
6. Sustaining the environment and future agricultural productivityIn parts of India, the over-pumping of water for agricultural use is leading to falling groundwater levels. Conversely, water-logging is leading to the build-up of salts in the soils of some irrigated areas. In rain-fed areas on the other hand, where the majority of the rural population live, agricultural practices need adapting to reduce soil erosion and increase the absorption of rainfall. Overexploited and degrading forest land need mitigation measures. There are proven solutions to nearly all of these problems. The most comprehensive is through watershed management programs, where communities engage in land planning and adopt agricultural practices that protect soils, increase water absorption and raise productivity through higher yields and crop diversification. At issue, however, is how to scale up such initiatives to cover larger areas of the country. Climate change must also be considered. More extreme events - droughts, floods, erratic rains - are expected and would have greatest impact in rain-fed areas. The watershed program, allied with initiatives from agricultural research and extension, may be the most suited agricultural program for promoting new varieties of crops and improved farm practices. But other thrusts, such as the livelihoods program and development of off-farm employment may also be key.

\section{Recent Government Policies Affecting Indian Agriculture:}

As part of its national agriculture program, India is prioritizing crops that require significant intensification, especially for fungicides. The focus on more sugarcane production, horticulture and continued growth in the production of grains can lead to a significant boon for the crop protection industry. Some major recent trends include:

1. Year of horticulture: Agriculture Secretary Mr. P.K. Basu said that the Ministry of Agriculture is giving significant thrust to the horticulture sector. The year 2012-13 has been declared as the "Year of Horticulture." Two conferences are going to be organized during the year. The first conference in February will focus on planting, material improvement and crop management while the second conference in November will be on post-harvest management and processing. Throughout the year, exhibitions will be held.

2. Government of India likely to allow fresh export of sugar: The Government of India is likely to allow 1 million tones of fresh sugar exports with an aim to help cash-strapped sugar mills take advantage of the higher export price and repay farmers of previous cane purchases. In early January, the Supreme Court asked the mills to repay within three months around Rs 9 billion (\$180 million) to farmers in the state of Uttar Pradesh for cane purchases made during 2006-2008.

3. Subsidized crop loans likely to be extended to farm equipment: The Ministry of Agriculture proposes to extend subsidized crop loan of $4 \%$ for agriculture mechanization. At present, the loan at the subsidized rate is only available for crop-related inputs such as seeds. Officials said the idea is to bring down farmers' labor costs, which account for around $25 \%$ of total costs.

4. Government of India to discontinue technological missions for cotton and jute: To give priority to food grain production, the Union Ministry of Agriculture has decided to end the technological missions for cotton and jute beginning in April. The move was partly prompted by farmers growing more cash crops beyond domestic demand. "In cotton, the acreage has gone up sharply year, in anticipation of higher prices. However, domestic demand is not much. Now, producers eye export market and there is no reason why the government will fund a crop to meet overseas demand," a government official said.

5. Cash transfer to farmers faces hurdle: The Indian Government buys rice, wheat and other crops from the farmers at a price known as "minimum support price" (MSP). The Food Ministry introduces this year a plan to transfer the MSP directly to the farmers' accounts or through account a check system, but it has run into roadblocks. The plan was strongly opposed by the cartel of middlemen and commission agents. Commission agents purchase grains from farmers at low rates and sell the produce to Food Corporation of India at MSP. If payments are made directly to the farmers, the middlemen will lose their commission.Many states have not yet adopted a system to directly transfer money to farmers for grains procured on behalf of Food Corporation of India (FCI), making the plan purposeless. In Punjab, one of India's biggest contributors of grains, the government is facing the biggest challenge in starting the process of direct payment, as the state has a wellestablished system of commission agents and middle men. The Food Corporation of India had to discontinue the process of direct payment during the current season midway because of dispute between FCI and commission agents. The direct payment system could allow smallholders to better manage input costs because of India's MSP predictability. 


\section{Conclusion:}

Agriculture makes the highest contribution to India's GDP. Agriculture contributes almost about 13.7 percent to the country's GDP. It has been seen in the last few years that the input of the agriculture sector has been declining, but it is still the biggest contributor. Agriculture occupies a prominent position in Indian policymaking not only because of its contribution to GDP but also because of the large proportion of the population that is dependent on the sector for its livelihood. However it is clear that India's agricultural sector has made huge strides in developing its potential. The green revolution massively increased the production of vital food grains and introduced technological innovations into agriculture. This progress is manifested in India's net trade position. Where once India had to depend on imports to feed its people, since 1990 it is a net exporter of agrifood products. Its agriculture is large and diverse and its sheer size means that even slight changes in its trade have significant effects on world agricultural markets. Training the farmers and educating them appropriately to change their mindset and reorienting them to take up new activities or adopt foreign technology is of utmost importance. In this context, it is necessary to involve non-governmental organizations in training and mobilizing the rural poor to face the challenge of liberalization. Also, with domestic economic reforms, more care needs to be exercised to draw up state-specific liberalization measures to maximize their benefits. Lastly, in the implementation of these reforms for successful globalization, one crucial element, not entirely within control is the need for good governance and stability in the political and economic environment.

\section{References:}

[1]. FICCI Economic Outlook Survey January 2011

[2]. Sen Gupta Saugar, 2004 .Planters Punch. The Pioneer, January 4, 2004, New Delhi.

[3]. Suresh A. and Pooran Chand, 2004 .Trade Related Aspects of Intellectual Property Rights., Kurukshetra, Vol. 52, No. 4, April 2004, New Delhi.

[4]. GOI (2008-09), Agricultural Statistics at a Glance, Ministry of Agriculture, (http://agricoop.nic.in/)

[5]. CSO (2007), "National Accounts Statistics 2007 and back issues", Central Statistical Organization, Ministry of Statistics and Programme Implementation, Government of India, New Delhi.

[6]. GoI (2006), "Towards Faster and More Inclusive Growth: An Approach to the 11th Five Year Plan (2007-2012)" Planning Commission, Govt. of India, December 2006.

[7]. Acharya, S.S., 1998. "Agricultural price policy and development: some facts and emerging issues",Indian Journal of Agricultural Economics, vol. 52, No. 1: 1-47.

[8]. Ahluwalia, M.S., 1996. "New economic policy and agriculture: some reflections", Indian Journal of Agricultural Economics, vol. 51, No. 3, pp. 412-426 